\title{
LOPE DE VEGA Y EL VIENTO
}

\section{INTRODUCGIÓN}

Una lectura rápida de la lírica lopesca nos revela inmediatamente que el poeta se inclinaba a repetir ciertas imágenes, a insistir en ciertos rasgos temáticos, a usar ciertos procedimientos. Esta preferencia, esta elección preferente, más que ser fortuita, se nos representa como algo fatal, esencialmente ligado a la vida de Lope, a sus gustos, a su intimidad. Si tratamos de aislar -aflorándolo en sus versos- cualquiera de esos temas o insistencias temáticas, subrayando las peculiaridades metafóricas que lo caracterizan, notaremos que el viento -el aire y el viento-, entre tantas otras imágenes de su predilección, traspasa toda su obra lírica de arriba abajo, al revés y al derecho.

Lope de Vega, come es sabido, se volcaba en cuanto hacía, vivía o escribía. Crear -más que recrear la vida- era un modo de vivir con una nueva profundidad. Así, le hallamos presente en cada verso, en cuerpo y alma, y, sin embargo, ningún poema le compendia por muy intenso que nos parezca, por muy cargado de vida que lo sintamos. Lope es todos ellos y aun muchos más: todos los escritos y los que están por escribir. Si la realidad poética es una transmutación de la experiencia vital, Lope de Vega -acaso por haber vivido una vida tan abundante e intensa- no llega a darse a conocer del todo, por completo. Su capacidad vital y artística es tan enorme que el lector teme no llegar a aprenderse nunca al "monstruo de la Naturaleza". Dolorido, garboso, alegre, lleno de donaire, enamorado, arrepentido, profundo, desbordante, etc., no deja nunca que el lector le atrape en su red, le encasille a su modo, le cace en su trampa, le explique según su propia tabla de valores. Lope rebasa todos los cánones y todas las clasificaciones, más allá de todo límite. Su fertilidad parece monstruosa a algunos; sobre todo a quienes todo lo miden escrupulosamente y en términos de cantidad. Por estas razones, más nos vale no juzgarle a la ligera. Abstenernos de definirle es lo más justo o, por lo menos, lo más cauto. Lope nos reserva siempre sorpresas que, antes de descubrirlas, ni siquiera sospechábamos. Lope -aunque a veces parezca repetirse- se está renovando 
a sí mismo constantemente: se autofertiliza, por decirlo así, y se reproduce y reengendra, superándose. Más que envejecerle, la experiencia vital y poética intensifica su apetito vital y su fuerza creadora, su hambre de amor y su hambre de darse.

Dámaso Alonso ve a Lope como una "torrentera" a la que se trasvasa "la vida del hombre en su pluralidad desenfrenada, día a día, en sus amores y en sus odios"'. Para otros críticos, es una fuerza de la Naturaleza, apasionada, violenta, sin tino. Para algunos, es río o es avalancha. Más que torrentera o riada, más que fuerza sin freno ni gobierno, a nosotros se nos aparece como un viento libérrimo que arrebata o eleva cuanto toca. Lope es un viento mudable, sí, pero al obedecer a esta ley del cambio, obedece a un nuevo orden, superior, que se cumple fatalmente. Sáinz de Robles reconoce - ¿con acrimonia? ¿conmiseradamente?-: "Muchos vientos sembró Lope. Y recogía tempestades"'2.

Sí. Lope de Vega era viento que se donaba a sí mismo generosamente. Amores suaves, amores turbulentos, desgracias y muertes, lágrimas, tormentas de odio, envidias, etc., eran parte de un proceso natural, de índole cósmica y humana al mismo tiempo.

También algunos de sus contemporáneos asocian a Lope con el viento. Sobradamente conocido es el soneto de Góngora "A la Arcadia de Lope de Vega", en el que se burla de sus pretensiones hidalgas, y que acaso escribió en respuesta a la epístola de Lope al licenciado Francisco de Rioja (cf. El jardin de Lope de Vega..., p. 133). Dice así el primer cuarteto (ed. Foulché-Delbosc, t. 3, núm. 429):

Por tu vida, Lopillo, que me borres las diez y nueve torres del escudo, porque, aunque todas son de viento, dudo que tengas viento para tantas tcires.

Quevedo, por su parte, al criticar el estilo llano y sencillo de Lope, le asocia con el viento $(B A E$, t. 69 , p. $48 b)$ : "Mal tus alas, tu vuelo y ligereza / sigue en flaco rocín corto galope". Baltasar Gracián, en cambio, le alaba como poeta popular, aunque no calla sus desigualdades, sus altibajos poéticos. La cita de Gracián (Criıicón, II, crisi Iv; ed. Romera-Navarro, t. 2, pp. 133-134) nos interesa ahora por cuanto relaciona a Lope con el viento, viento del pueblo aquí:

Resonava mucho y embaraçava a muchos un instrumento que unieron cáñamo y cera. Parecía órgano por lo desigual y era com-

${ }^{1}$ Dámaso Alonso, Poesia española: Ensayo de métodos y limites estilisticos, Madrid, 1957, p. 421.

2 "Nota preliminar" a las Obras escogidas: poesia y prosa de LOPE DE VEGA, Madrid, 1953, p. 14. Por esta edición (salvo indicación en contrario) citaremos en adelante todas las obras de Lope. 
puesto de las cañas de Siringa, cogidas en la más fértil vega. Llenávase de viento popular; mas con todo este aplauso, no les satisfizo, y dijo entonces la poética Belleza:

-Pues sabed que éste, en aquel tiempo desaliñado, fue bien oído, y llenó por lo plausible todos los teatros de España.

El viento, pues, vincula a Lope a su pueblo. Lope deviene así "viento de España", "viento del pueblo de España". Y porque estamos convencidos de ello, intentamos hoy esta indagación temática y estilística.

¿Por qué entresijos se mete este viento que pasa por su vida y por sus versos? ¿Qué hojarascas arrastra? ¿O se cuela desnudo, delgado, grácil, sin que nadie acierte a darse cuenta? ¿Qué significados metafóricos encubren su nudez? Tratemos de seguir la senda sutilísima que abre el viento en la múltiple y riquísima selva lírica de Lope. No dejemos que se pierda el soplo delicado de este viento que no siempre es el mismo, que no siempre es diáfano o suave. Ascendamos a sus elevadas galerías. Nos proporcionará sorpresas, de seguro: porque siempre ocurre así cuando uno se adentra en el arte de Lope.

Tras suprimir obvias significaciones ${ }^{3}$, procedamos con método. Pero ¿cómo ordenar el viento? ¿Cómo poner en orden los turbiones del vendaval? Nos inclinamos a aislar sus funciones y matices, categorizándolos de algún modo. Preferimos partir del mundo exterior -mundo en el que el viento se mueve físicamente- y avanzar hacia dentro hasta alcanzar los más puros centros interiores, la intimidad del hombre: su alma, su espíritu y su pensamiento. Podríamos invertir este orden y nada ocurriría, mas perderíamos el sentido de ese proceso de interiorización (aunque nada tenga que ver con la cronología genética), ese ascenso -o descenso- que paulatinamente ha de llevarnos a una culminación.

Antes de sumirnos en la Naturaleza, hemos de recordar que Lope se halla inserto en una doble tradición literaria y cultural, irrenunciable en sus dos vertientes de honda raigambre: la tradición culta y la tradición popular. A causa de ellas, el viento lopesco se tiñe de matices mitológicos y de rasgos folklóricos, claramente diferenciados.

\section{EL VIENTO DE LA TRADICIÓN LITERARIA}

1) El viento mitológico. Buen conocedor de la mitología, Lope de Vega no podía dejar de mencionar a los vientos -alguna vez,

s Éstas abundan - ¿cómo no?-, pero los versos bellos predominan. En el viento flamean gallardetes, pendones, banderolas y cimeras, que le sirven de "alas" (Jerusalén conquistada, p. 7og). Es el elemento que impulsa y aviva Iumi. narias (Fiestas de Denia, p. 482) e incendios (Gatomaquia, p. 918). 
al menos- con sus nombres mitológicos específicos, animando y vivificando así el paisaje del mismo modo que lo hicieron los antiguos. Sírvanos de paradigma un pasaje de la silva moral "El Siglo de Oro" (p. 236), en que Lope da a los vientos cardinales sus nombres clásicos, especificando además su procedencia geográfica.

A la parte oriental, Euro tendía

las alas vagarosas, el Austro y Mediodía, y Bóreas fiero a las distantes Osas por el Septentrión temor ponía...

El suave y favorable Céfiro inicia un bellísimo soneto de las Rimas: "Céfiro blando, que mis quejas tristes / tantas veces llevaste..." (p. 53), y vuelve a aparecer en la égloga "Amarilis", tomando sus colores de las flores (p. 186). La suavidad del Céfiro es perceptible en unos versos de La hermosura de Angélica (p. 513): "sólo se escucha entre la rama y hoja / el céfiro que juega...", y en el mismo poema (p. 548) se hace visible el matiz mítico de los vientos, cuando la maga Mitilene enumera sus poderes: "Las alas de los Vientos encadeno, / que no se escapa de su cueva alguno".

2) El viento folklórico. En los versos en que tal viento se muestra con su oreante perfume, es difícil aseverar qué palabras o imágenes son originales, o reelaboradas, o provienen directamente de la tradición lírica popular de España: la misma agua antigua se vierte en un cántaro joven, en una nueva arcilla que decanta y depura. Bástenos recordar aquí estos dos encantadores y deliciosos ejemplos en los que el viento absorbe un lirismo alígero y sencillo (pp. 44 y 17 ):

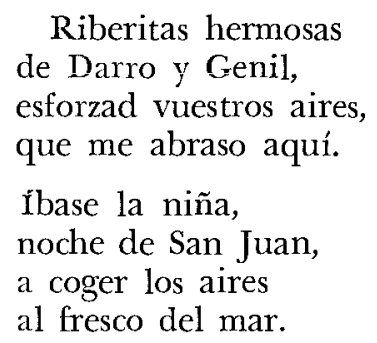

(Nótese cómo en el segundo cantarcillo el aire tiene calidad y presencia tangible: es una especie de objeto deleitoso o de materia palpable como una fruta).

\section{EL VIENTO Y LAS SENSACIONES}

El viento, al cruzar por los versos de Lope, sugiere diversas sensaciones o implica cualidades sensoriales que sirven para acentuar la matización poética. Nos es posible agruparlas en cuatro catego- 
rías: I) luminosidad y cromatismo; 2) sonido y musicalidad; 3) fragancia: 4) corporeidad visual y táctil.

I) Lope observa la diafanidad aérea del viento en la égloga elegíaca que dedica a su hijito ("Felicio en la muerte de don Lope Félix del Carpio y Luján"), al aludir a la rapidez inesperada de su pérdida: "ni en el campo dïáfano del viento / feroz halcón se abate..." (p. 269). Pero con anterioridad ha contemplado la tonalidad aérea de los céfiros ("Ya con el oro céfiros süaves", p. 268). El color del aire es a veces sugerido por las cosas o elementos que en él flotan; el viento, por sí mismo sin color, absorbe los matices de cuanto toca impalpablemente. En La hermosura de Angélica (p. 587), Rostubaldo

sale bizarro de morado y verde, verde el bonete y con morada toca, un morado penacho, que se pierde por irse al aire, que su extremo toca.

En un pasaje de la Jerusalén conquistada (p. 620),

un corvo y persa alfanje de dos filos hizo rayo del sol, porque, desnudo, vestir el aire de centellas pudo,

ejemplo claro de absorción cromática al que podemos añadir otro, de matiz más hiperbólico, pero muy efectivo poéticamente, en que Lope se dirige al Tirreno como a un dios marino que sube a la superficie "ceñido de corales, que enrojecen / el aire en que aparecen" ("A la venida de Italia del... Duque de Osuna", p. 248).

2) El viento, esencialmente, crea sensaciones acústicas: a) agitando árboles y plantas - "al pie de un lauro, haciendo son al viento" (Rimas, p. 62)-; b) pulsando, humanizado, instrumentos musicales delicados, arpas y liras _ "que cuando por los árboles sombríos / el instrumento que a los vientos suena / colguemos..." (Jerusalén conquistada, p. 635)-; c) recogiendo sones broncos de trompetas y tambores bélicos, que en él retumban magnificados ${ }^{4}$; d) transmitiendo airadas y desafiantes voces humanas que poetiza en ecos - "los ecos vuelan por el aire frío" (Fiestas de Denia, p. 481) - o quejas sufrientes (Jerusalén conquistada, p. 719):

De la manera que en la cárcel suele hacer aquel rumor de varios presos,

“ Los ejemplos abundan en la Jerusalén conquistada: "y ya por otra parte las bastardas / trompetas tal furor al aire ofrecen, / que los semones dioses estremecen" (p. 686); "ya se mezclan, se traban y se meten / haciendo retumbar el aire mudo" (p. 7o6); "las cajas luego el aire ensordecieron / del alba a Tetis su silencio roto" (p. 648). Cf. también "Felicio en la muerte de don Lope Félix del Carpio y Luján" (p. 265): "Oye la ronca salva / que los albores oscurece al alba / con horrísonos tiros / que van haciendo por el aire giros". 
que un son horrendo por los aires vuele de quejas, grillos, voces y procesos...

3) El viento esparce también sensaciones olfativas delicadas absorbidas de la Naturaleza, que Lope recuerda al evocar la fragancia del Jordán - "espiraba un olor divino el viento, / más que bañado en cinamomo y casia" (Jerusalén, p. 830)- o de una mujer hermosa -ienamorado Lope!- (Arcadia, p. 1097):

$\mathrm{Ni}$ tal olor diera al viento el jazmín y azahar cortado, si no se lo hubiera dado vuestro delicado aliento.

4) El Fénix poetiza la presencia del viento, corporeizándolo plásticamente en la Gatomaquia, cuando Marramaquiz corteja a Zapaquilda (p. 912):

Estaba el sol apenas matizando las plumas de las alas de los vientos, dando a los dos primeros elementos, esmeraldas al uno, al otro plata...

Lope, finalmente, complica su técnica sensorial y cristaliza sinestésicamente el color y el perfume cruzando además esta doble sensación con otra acústico-musical (Jerusalén, p. 644):

las nablas, de los ámbares lustrosos, aromática lágrima a los vientos endurecida, y del color del oro, formó... .

\section{El viento y la Naturaleza}

Dámaso Alonso, después de transcribir el soneto de Lope a Lucinda ("Ya no quiero más bien que sólo amaros", p. 61), exclama: "¡Qué oleada de viento, qué sensación de Naturaleza! ¡Cómo se hinchan los versos sencillos y apasionados, diríamos románticos!" (op cit., p. 423). De acuerdo. Lope de Vega, hijo de la Naturaleza -y por ser fuerza de ella, monstruo-, vital, exuberante, desenfrenado, pasión y corazón, poeta del cielo y de la tierra, cuya poesía traduce su vida vivida y los vuelos de su imaginación, merece como nadie ser el poeta del viento, al ser viento él mismo: viento humano, erótico, viento de la Naturaleza. De ahí que este último impregne muchísimos versos en variadas imágenes poéticas. Dice también Dámaso Alonso (op. cit., p. 476):

Lope parece adelantarse a todos los miembros de su generación..., y tiene tan grabada la abundancia y variedad de las formas de la naturaleza, que las series descriptivas surgen en todas 
partes en su poesía: lo mismo en sus canciones populares que en su lírica italianizante, que en su teatro; esta plenitud que le traspasa, característicamente barroca, viene a ser también caracterizadoramente suya.

¿Cómo aparece el viento en la extensísima obra de Lope y dentro del variado fondo de una superabundante Naturaleza cósmica que el poeta ama y exalta infinitamente? Si procuramos ordenar de alguna manera las citas halladas, podríamos establecer las siguientes amplias clasificaciones: $x$ ) flora; 2) fauna; 3) el viento y el mar; 4) el viento y la creación del mundo. Iremos de lo más inmediato y cercano a lo que está más lejos, en progresión ascendente. En las dos primeras categorías, el viento asume calidades y funciones eglógicas, por las cuales enlaza Lope sus imágenes con la tradición clásica, aunque siempre sabe teñirlas con el sello de su originalidad lírica.

1) El viento y la flora. Bajo este encabezado es posible establecer dos grupos bien caracterizados: $a$ ) flores; $b$ ) plantas y árboles.

a) En forma de suave céfiro, el viento baña sus alas en las flores para tomar sus colores (égloga "Amarilis", p. 186):

que parece que vuelan clavellinas, o que los frescos aires encontrados se tiran flores en los cielos prados.

En un poema de circunstancias ("Versos a la primera fiesta del Palacio Nuevo", p. 247), las flores van por los aires, esparciendo color en primavera:

¿Quién vio cuadros de flores ir por los aires vagos? ¿Quién abriles tirándose colores?

El aire de abril abre lirios matinales cuando el poeta evoca a San Isidro -el de su cuerpo incorrupto- como si fuera un campo florido (El Isidro, p. $4^{6} 7$ ):

Dad, pues, vegas mantüanas, que la fuente santa riega, a petición de otro Vega, los lirios que en sus mañanas abril al aire despliega.

No todo es aire suave en una Naturaleza idílica. El viento se encoleriza de pronto y, furioso, derriba flores, destruye ramas, deshace huertos: "Así del viento bárbaro rigores / rompieron ramas y sembraron flores" ("Huerto deshecho", p. 261).

b) En La hermosura de Angélica, "mueve las hojas de la selva el viento" (p. 554). En la Jerusalén conquistada, el viento asalta las riberas, arrancando las hojas y arrastrando ramas en su remolino 
(p. 682). Pero luego se esconde, y entonces cesa el movimiento de las hojas (p. 785 ). Lope describe después un bosque sagrado "adonde apenas ave / osó anidar, ni el atrevido viento / libre turbar aquel silencio grave" (p. 831). En la "Égloga segunda" a Lucinda, el viento se requiebra amorosamente con las hojas, en tanto que Elisio llora y tiene conciencia de que, en torno, la Naturaleza es feliz e indiferente a su pena (p. 77).

2) El viento y la fauna. El viento -es obvio decirlo- es el elemento natural en que viven y vuelan las aves. Lope lo afirma en cstos versos: "huyen las aves que en su cuerpo encierra / el claro viento con sus alas vanas" (La hermosura de Angélica, p. 538). (Adviértase cómo el sesgo poético de la imagen ha deshecho el lugar común). Las aves, además, "con dulce melodía / animaban los céfiros süaves, / que también en las flores eran aves" (Rimas humanas. .., p. 225). El aire adquiere matices eglógicos cuando Lope, en su elemento, entona un canto a las aves ("Égloga primera", pp. $69-70)$ :

Aves que por el aire discurriendo unas por otras vais enamoradas, formando quejas dulces y amorosas, más que del sol, adonde vais subiendo, de amores encendidos abrasadas, bajad a aquestas selvas espaciosas...

Aves que vais el viento enamorando con versos no entendidos de los hombres...

(Obsérvese con qué finura ha sabido Lope trasfundir encendimiento amoroso a viento y avecillas).

Las aves que el poeta relaciona con el viento son muchas y variadas. A veces no les da un nombre específico, sino que utiliza el genérico de "pájaro" o "pajarillo", cuando el interés del verso se centra en otro aspecto de él mismo. No obstante, el "pajarillo" -al huir de su jaula "al libre viento"- puede ser elemento central, aunque al poeta no parece importarle que sea canario o jilguero: lo importante es que la avecilla le sirve para demostrar el poder de las lágrimas, en este caso, de su amada Lucinda (Rimas, pp. 65-66):

Daba sustento a un pajarillo un día Lucinda, y por los hierros del portillo fuésele de la jaula el pajarillo al libre viento en que vivir solía...

"¿Adónde vas, por despreciar el nido, al peligro de ligas y de balas, y el dueño huyes que tu pico adora?" Oyóla el pajarillo enternecido, y a la antigua prisión volvió las alas: que tanto puede la mujer que llora. 
Otros pájaros, por el contrario, rehusan la domesticidad y se lanzan a los cielos y a los aires libres, sin humillarse (La hermosura de Angélica, p. 588):

el rojo y blanco pájaro celeste, que nunca a tierra el alto vuelo humilla, lo más puro del aire rompe y hiere, en él engendra, nace, vive y muere.

$\mathrm{O}$, sencillamente, conciertan cantos con el viento (Fiestas de Denia, p. 471): "El viento con los pájaros se acuerda, / en concertados números cantando".

El viento está poblado de aves, pero un glotón sibarita puede "despoblarlo" con sus redes ("A un glotón", p. 279). El viento, además, no siempre las tolera en su elemento, sino que, "airado, / suele arrojar el pájaro del nido" (La Arcadia, p. 1080).

Los nombres de pájaros -desde los más pequeños y apacibles hasta los de caza- que Lope especifica son: el jilguero - "puso mano enemiga / a la pintada pluma del jilguero / laberintos de liga"-; la paloma - “'Por ventura en ejército volante / esparció tus palomas por el viento / el rayo de la pólvora tronante?"-; la tórtola - "Tomó una piedra el pastor / y esparció en el aire claro / ramas, tórtolas y nido"-; las garzas -que no pueden volar "tan altas por los vientos"-; el nebli - "rompiendo el viento, / las extendidas alas endereza"-; los sacres "furiosos"s.

Combinados o en contraste, Lope mezcla en un mismo poema los nombres -en función alegórica algunas veces- de pájaros como el jilguero, el gorrión, el azor y el águila, en un soneto en que el poeta denuesta al gorrión y desea que sea devorado por el águila "en tejado o en el viento", interpretando el enojo de una dama a quien el gorrión mordió la lengua (p. 219). La perdiz, aterrorizada, detiene su carrera cuando el halcón esparce "su vuelo en el viento" (p. 271). El halcón también abate en el viento "a la rendida garza" ("Felicio...", p. 265).

No sólo las aves tienen que ver con el viento en la poesía lopesca. Los peces se asoman desde el fondo del mar para escuchar la voz de San Antonio: "sacan las frentes a los aires claros" (Rimas sacras, 83). También gatos y caballos. En la Gatomaquia, lámese la cola "la bella Zapaquilda al fresco viento" y, después, "enamoraba al viento" (p. 893). En El mejor alcalde, el rey, Nuño alaba su caballo, com. parándolo con el viento: "Yo tengo un rocín castaño, / que apostará con el viento / sus crines contra sus alas, / sus clavos contra su freno"

s Jilguero: "Al Padre Maestro fray Ponciano Basurto", p. 1o7; palomas: égloga "Filis", p. 202; tórtolas: romance "El tronco de ovas vestido", p. 286; garzas: Gatomaquia, p. 9og; neblí: "Égloga en la muerte de... fray Hortensio Félix Paravicino", p. 254; sacres: La hermosura de Angélica, p. 544. 
(Acad, t. 8, p. 313a). En la Jerusalén conquistada, los caballos corren tan velozmente que al viento "hacían / quedarse atrás con las espuelas duras" (p. 669).

3) El viento y el mar. Estos dos elementos cósmicos se combinan muchas veces en los versos de Lope. Así aparecen juntos en el soneto "De Jasón" (p. $5^{6}$ ), de corte muy clásico en cuanto a tema e imágenes convencionales:

$\mathrm{Y}$ aunque Anfitrite airada se consuma, dividen el cristal sus ninfas bellas, y hasta Colcos Jasón pasa por ellas, por más que el viento resistir presuma.

En el soneto "A don Félix Arias Girón" (p. 59), el poeta suplica a ambos elementos que aseguren el retorno de la armada católica a las playas de la patria:

Océano mar, que desde el frío Arturo las antárticas márgenes combates, así con vientos prósperos dilates las ondas de tu campo crespo y puro, que a la armada católica seguro una laguna de cristal retrates...

En la "Canción que la congregación de los sacerdotes naturales de Madrid dedica al serenísimo señor don Fernando de Austria..." (p. 245), hallamos un pequeño paisaje de mar y viento, en que una nave es suavemente impulsada:

El viento soberano la socorre con blando soplo en las hinchadas velas, humillando los cercos de las olas.

En cambio, en La hermosura de Angélica vemos, en vivida descripción, cómo el viento detiene y luego arrebata una nave, "un pobre leño que el furor contrasta/del fiero viento que las ondas crece" (p. 527$)^{6}$.

4) El viento y la creación del mundo. Lope introdujo en sus Rimas una égloga que tituló "A la creación del mundo". En ella, Dios fabrica el orbe con todos sus elementos, entre los cuales no falta el viento. Éste va y viene, por encima de la tierra y el mar. Por él vuelan las águilas, los alciones, "el ánade caluroso", "la piadosa cigüeña", "las palomas de Venus", los psítacos, los faisanes, las garzas y martinetes... (p. 89 ),

En fin, cuantas visten plumas al claro viento descogen

${ }_{6}^{6}$ Cf. también pp. 549, 550, 595. Otras referencias al viento y al mar en la Jerusalén conquistada, pp. $83^{8}$ y 857 . 
las alas, y en rama o peña

duermen, anidan y ponen.

En esta égloga, muestra perfecta del amor que Lope siente por la Naturaleza, el viento se destaca no sólo con fuerza dinámica, sino también vivificante.

EL VIENTO Y LA GUERRA

La Jerusalén conquistada -extenso poema al que Lope dedicó fervor y paciencia durante muchos años porque soñaba emular con él a Tasso- contiene versos y escenas en que el viento -como es fácil suponer- desempeña un papel bélico, sirviendo de fondo a las batallas. En él se desdoblan y tremolan las banderas, cruzan y silban las flechas. Él activa los incendios y, a veces, las espadas pueden dividirlo (cf. pp. 65o, 721, 741, 748, 8o 7 et passim).

\section{EL VIENTo hUMANO}

El aire y el viento adquieren en muchas ocasiones, al soplar por los versos de Lope, formas e imágenes humanadas. Transparentan actitudes propias de los hombres, poseen rasgos y perfiles que sólo a éstos pertenecen, poéticamente transfigurados por el exultante lirismo lopesco, por su incontenible vitalidad. Por vía de un epíteto metafórico, de un verbo que denota una acción humana o implica un sentimiento, o por medio de otros matices expresivos, el aire y el viento se humanizan. Esta gama tropológica podría ordenarse en planos de progresión intensificadora, externa e interna, arrancando en los juegos metafóricos más obvios.

En una seguidilla (p. 17), los vientos se aniñan, pequeñitos, juguetones, saltarines:

$$
\begin{aligned}
& \text { No corráis, vientecillos, } \\
& \text { con tanta prisa, } \\
& \text { porque al son de las aguas } \\
& \text { duerme la niña. }
\end{aligned}
$$

En un soneto (p. 67), Lope insinúa en el viento unas manos, un cuerpo..., pues sostiene, levanta unos papeles rotos que son pesadas reliquias -“¡hijos del alma!”- para el poeta:

Papeles rotos de las propias manos que os estimaron por reliquia santa, bien muestra ahora el viento que os levanta que, cuando más pesados, sois livianos...

Tales manos se configuran claramente en unos versos de la Jerusalén (p. 876 ) en que, además, aparece el viento dotado de voz y humanizado en músico: 
el cielo con relámpagos y truenos

da voz al viento, músico enojoso...

Las cuerdas todas ya del instrumento

de sus fuertes clavijas se desatan,

porque en las manos del airado viento

el sonoro concierto desbaratan.

Y tiene voz el viento en la epístola "A don Antonio Hurtado de Mendoza" al alabar a Felipe IV (p. 160). También proclama la fama de la hermosura de Angélica (p. $5^{16}$ ), y sabe recoger suspiros (p. 495). Todavía más: en una Naturaleza humanizada, es capaz de escuchar el llanto de Andrómeda, en tanto que el sol la contempla y el mar la besa (Rimas, p. 56). Y - con los demás elementos- puede acompañar en su pena al hombre, enmudecer, suspenderse, admirarse. El viento es sensible, en consecuencia, al dolor de Lucinda en la égloga que recita Montano en La Arcadia (p. 1126). Compasivo, lleva cartas de amor (de Lucindo a Clori, p. 1128). Sabe también transmitir, en forma de "céfiro blando", las "quejas tristes" (p. 53) del amante, y decirle a la amada desdeñosa que por ella muere.

Cuando suena la música militar, a Lope le "parece que se queja el viento" con furioso aliento humano (Jerusalén, p. 851). El viento, sensitivo, recoge todavía las esperanzas del que se destierra de España, del que se aparta físicamente pero que se queda en ella ( $\mathrm{La}$ Arcadia, p. 1080). Y puede devolver así las esperanzas que le piden (Jerusalén, p. 696). En otra ocasión gobierna a los hombres, convirtiéndose en su propio destino: "que aqui llegué por voluntad del viento" (p. 705).

Ante la presencia del rey, y porque reinan la primavera y la alegría, el aire se enamora (Fiestas de Denia, p. 471). El viento es capaz de sentir anhelos sexuales y de responder al deseo lascivo de Juno ("A la venida... del Duque de Osuna", p. 248). Acaso este mismo impulso hincha las velas de las naves. Lope, viendo en todo lo criado ansias amorosas, intensifica la vivificación: "Iban las velas hinchadas, / del claro viento preñadas" (El Isidro, p. 4o6), imagen que se repite en las Fiestas de Denia (p. 482).

El viento le sirve a Lope como imagen metafórica para indicar velocidad y rapidez en los actos humanos: "siendo para probar su pensamiento / cuerpo al herir, y para herirle viento" (Jerusalén, p. $\left.7^{06}\right)^{7}$. Además de prisa y celeridad, connota cólera: "Salió de la ciudad bebiendo viento / y dando al suelo que pisaba espanto" ( $\mathrm{La}$ hermosura de Angélica, p. 602). Finalmente, el viento humanizado

${ }^{\tau}$ Parecida imagen se repite en La hermosura de Angélica (p. 579): Rostubaldo, al correr, "el viento iguala". 
se introduce en la vida cotidiana, en el ambiente rústico y en los actos de Juan de Vargas (El Isidro, p. 412):

En fin, un tizón halló

y algunas pajas juntó

sobre el extremo quemado,

y el rostro, de viento hinchado, soplando, resplandeció.

\section{EL VIENTO ENAMORADO ${ }^{8}$}

Lope, mudable como el viento en sus amores, no podía dejar de utilizar su imagen -cambiante o fugitiva, suave o turbulenta, favorable o desdeñosa, huracanada o tranquila- en sus versos amorosos. En ellos, el viento actúa en variadas funciones, plegándose siempre a las exigencias de la pasión, matizando el sentimiento amoroso, participando poéticamente en el drama erótico. A veces es difícil aislarlo, separándolo del poeta, pues ha devenido él mismo. Otras - cuando su identificación con Lope es menos intensa o menos evidente- sigue o rodea o se adelanta al enamorado o a la mujer amada. Si cela o asedia a ésta, el viento es como la presencia simbólica del amante, o el confidente del amor, o latente impulso apasionado. Y, de este modo, suplica amor (Jerusalén, p. 876):

¡Oh ninfas de Anfitrite! ¡oh verde coro a quien los vientos blandamente ruegan que les tengáis amor...!

El viento es fuerza poderosa que aniquila montañas (Jerusalén, p. 797). O recoge suspiros, quejas, esperanzas ${ }^{9}$. Recibe pensamientos encendidos o palabras de amor ${ }^{10}$. A veces, es movido a pasión ( $L a$ hermosura de Angélica, p. 56o):

que amor de todos medios se socorre, por donde el viento, a lástima movido, traía las razones al oído.

Pero hay ocasiones -cuando el amor parece inalcanzable o se sabe fugitivo- en que el viento se identifica totalmente con esta condición huidiza del amor, inestable, volandera: "los bienes que pensé gozar de asiento / huyeron más que el aire fugitivo" (Rimas, p. $\left.5^{1}\right)^{11}$. Y hay poemas en que llega a confundirse con el definitivo

${ }^{s}$ Sugerido por el título de la comedia de Lope El Amor enamorado, y por el verso de la Jerusalén conquistada (p. 712): "y al cielo dijo, enamorando el viento".

" "Claros aires de Valencia...", p. 18; Rimas, p. 6o; La Arcadia, pp. 1145 y 1149; El Isidro, p. 425; "Liras amorosas", p. 271.

${ }^{10}$ La hermosura de Angélica, p. 542; Jerusalén, pp. 675, 710, 770.

${ }^{11}$ Cf. también El Isidro, p. 428; La Arcadia, p. 1058. 
desengaño: "Al viento se encomienda, al mar se entrega... / quien pone su esperanza en mujer flaca" (Rimas, p. 61); "si toda esperanza mía / nace monte y muere viento, / ¿cómo dura mi tormento?" ( $L a$ Dorotea, p. 1536); "llevóse el viento el pájaro y la gloria / y dejóme el cordel entre las manos, / que habrá por fuerza de servirme al cuello" (Rimas, p. 64).

El amor puede ser inalcanzable o imposible. El amante -Leriano- se queja del rigor desdeñoso de la amada con este adynaton en que culmina la imposibilidad (La Arcadia, p. 1058):

si se ablandare la enemiga mía...

clara será la noche, oscuro el día,

el aire tendrá cuerpo, el mar sosiego.

Los mudables estados psicológicos del amor, sus crisis sentimentales, quedan indicados por el viento en estos versos de leve humor que canta Silvia (La Arcadia, p. 1123):

¡Qué mala usanza de torre! Pues luego que a veros viene, conoce el viento que corre por la veleta que tiene.

La imagen del viento le sirve a Lope para interpretar certeramente los celos (El caballero de Olmedo, II; $A$ cad, t. 10, p. 167b):

Son celos, don Rodrigo, una quimera que se forma de envidia, viento y sombra, con que lo incierto imaginado altera;

una fantasma que de noche asombra, un pensamiento que a locura inclina, y una mentira que verdad se nombra.

El aire mismo puede causar celos, según canta en La Dorotea Don Fernando (personaje que, como es sabido, representa al propio Lope): “¿Eres tú la bien prendida, / aunque es mejor que te llamen / la que cuanto mira prende / y tiene celos del aire?"

En fin, también el deseo sexual aparece representado metafóricamente por el viento (La hermosura de Angélica, p. 574):

Tiemblan los dos, cobardes y difuntos, justa es la fuerza, la razón lo pide, como tiemblan los árboles, que juntos el viento los abraza y los divide.

El VIENTO TEMPORAL

En ciertas ocasiones, Lope asocia el viento con el tiempo en algunas de sus formas, en imágenes o comparaciones de significación humano-temporal. De este modo, connota transitoriedad, a la 
que todo está condenado: los hombres y la Naturaleza. Así en La hermosura de Angélica (p. 505):

¡Oh vanidad, que despeñó del cielo

de las estrellas la tercera parte, pintura natural en sutil velo, favorecida de colores y arte; nieve al sol, pluma al viento, flor al hielo, atambor engañoso y estandarte que llamas y conduces a la muerte al mozo, al viejo, al sabio, al flaco, al fuerte!

y en la canción "A la muerte de Carlos Félix" (p. 105):

Póstrase nuestra vil naturaleza a vuestra voluntad, imperio sumo, autor de nuestro límite, Dios santo. No repugne jamás nuestra bajeza, sueño de sombra, polvo, viento y humo, a lo que vos queréis, que podéis tanto.

La transitoriedad fugaz del vivir humano se siente aún más patética en uno de los poemas más profundos de Lope: la epístola "A don Juan de Arguijo", donde hace examen de conciencia, pesa su edad, evalúa su vida y presiente el avance de la muerte, haciendo universal su resignada aunque angustiosa certeza personal (p. 155):

En humilde fortuna más contento aquí, señor don Juan, la vida paso: ella pasa por mí, yo por el viento...

Semejante preocupación temporal es evidente también en la "Égloga a Claudio" (pp. 255-261): el curso de la vida humana se aparece ante Lope como una "incierta vía" de sombras, en la que aguarda a los hombres -y a todo lo creado- el "feroz cierzo de la Muerte":

Sólo conoce de su incierta vía los vientos, que es lo mismo que los hombres...

Todo lo juzgo sombras, todo viento, todo opinión y fuerza poderosa...

Las pajas de su nido sacudiendo cuelgan del aire tiernas filomenas, y estampa las arenas el perdigón corriendo, antes que el viento acuchillar presuma la cáscara del huevo entre la pluma...

Bien es verdad que temo el lucimiento de tantas metafísicas violencias, fundado en apariencias; 
engaño que hace el viento, herida la campana en el oído, que parece concepto y es sonido.

En función temporal, el viento simboliza el transcurso de las estaciones y, concretamente, del otoño -símbolo, por su parte, de la vejez y decadencia a que está condenada la creación y el hombre mismo (Gatomaquia, p. 905):

No suele por los fines del otoño quedar la vid ñudosa en los sarmientos de los marchitos pámpanos robada, sin resistencia a los primeros vientos que con nevado soplo y boca helada cierzo dejó cadáver con la fiera mano que floreció la primavera... ${ }^{12}$

Finalmente, el sentido temporal del viento presenta un nuevo matiz en La Arcadia (p. 1061), significando las circunstancias adversas, los cambios de fortuna que asedian la vida humana y destruyen la fe del hombre: "Mirad, pensamiento, / que la fe más alta / a cualquiera viento / en los hombres falta".

\section{EL VIENTo DEL ENGAÑo Y DESENGAÑo}

Henos aquí ante otra significación que penetra la imagen del viento: es el valor moral. En él se advierten diversos matices que culminan en el profundo desengaño de Lope ante sí mismo y ante el mundo. Tracemos la progresión intensificadora de tal proceso.

En El Isidro, el poeta nos dice que al santo "quedóle aquel viento manso / de la humildad para aliento" (p. 373). Lope confiere, pues, al viento un primer matiz moral de mansedumbre y santidad. En El caballero de Olmedo hallamos otro matiz: del viento emana tristeza, que acentúa la melancolía de don Alonso (Acad, t. 10, p. $18 \mathrm{o} b)$ :

Lo que jamás he tenido, que es algún recelo o miedo, llevo caminando a Olmedo.

Pero tristezas han sido. Del agua el manso rüido

y el ligero movimiento destas ramas con el viento mi tristeza aumenta más...

Este matiz reaparece en un soneto de las Rimas: el viento encarna

${ }^{12}$ Cf. también Jenisalén, p. 802: "Pero de la manera que arrebata / viento veloz las hojas de noviembre..." 
la tristeza que se lleva toda esperanza: “y llevaráse mi esperanza el viento" (p. 58).

El viento también puede significar el engaño: anhelos, ilusiones, pensamientos, provechos falsamente edificados en el aire (Rimas, p. $5^{8)}$ :

Cayó la torre que en el viento hacian

mis altos pensamientos castigados, que yacen por el suelo derribados cuando con sus extremos competian ${ }^{13}$.

Estos engaños, este viento engañoso conduce al poeta -a Lope y al hombre de todos los tiempos- al desengaño del amor, a la congoja existencial (La Dorotea, p. 1463 ):

Traidoras son las aguas; ninguna se confíe de condición tan fácil, que a todos vientos sirve...

No intentes nuevas tablas ni el viento desafíes, que rüinas del tiempo ninguna enmienda admiten...

No te anuncien las aves tempestades terribles, ni el ver que entre las ramas airado el viento silbe ${ }^{14}$.

Hombre de caídas y arrepentimientos, Lope nos aclara -por si tuviéramos dudas- el significado preciso que confiere al viento (Soliloquios de un alma a Dios, pp. 1033, 1040):

Todas las cosas de la tierra son vanidad y aflicción de espíritu; todas las confianzas del hombre, maldiciones vuestras; todas las promesas, engaño; todos los deseos, viento, y todas las voluntades, mentira...

¿Cómo podrán volver atrás mi viaje los procelosos vientos de mis inclinaciones, ni las inquietas olas de mis costumbres?

Nos hallamos ante un viento de significación moral: el viento del deseo y de las pasiones. Viento que arrastró a Lope al desengaño, pero que volvió a levantarle y que otra vez tornó a abatirle. Y este desengaño culmina en sus Rimas sacras. Todo cuanto ha pensado y pretendido es sólo vanidad, sombra y engaño: viento. También es viento la "vida breve", la "verde edad" y la "hermosura mortal":

${ }^{13}$ Cf. también La Arcadia, p. 1173: "Todo lo provechoso, comparado / con la felicidad eterna, es viento..."

${ }^{14}$ Cf. también "Pobre barquilla mía” (ibid., p. 1482): “¿Qué jarcias te en tretejen? / ¿Qué ricas banderolas / azote son del viento / y de las aguas sombra? / . . Ya fieros huracanes / tan arrogantes soplan, / que, salpicando estrellas, / del sol la frente mojan". 
Si no tengo de todo lo pasado presente más que el tiempo que he perdido, vanamente he cansado mi sentido, $y$ torres en el viento fabricado.

Imprime ahora, oh fuerza soberana, tus efectos en mí, que es imposible conservarse mi ser incorruptible, viento, humo, polvo y esperanza vana.

Así la verde edad se esparce al viento, y así las esperanzas son aleves que tienen en la tierra el fundamento.

iOh hermosura mortal, cometa al viento! ¡Donde tan alta presunción vivía, desprecian los gusanos aposento!

¡Oh engaño de los hombres, vida breve, loca ambición al aire vago asida! pues el que más se acerca a la partida, más confiado de quedar se atreve.

iOh flor al hielo, oh rama al viento leve lejos del tronco! si en llamarte vida tú misma estás diciendo que eres ida, ¿qué vanidad tu pensamiento mueve?

Dulce señor, mis vanos pensamientos fundados en el viento me acometen, pero por más que mi quietud inquieten, no podrán derribar tus fundamentos... ${ }^{15}$

EL VIENTO Y EL ÁNGEL

En 1612 publicó Lope de Vega sus Pastores de Belén, novela pastoril a lo divino, cuya prosa y verso presentan los temas idílicos de la devoción popular y los temas históricos de la devoción erudita. El poeta relata aquí las vidas de María y de Jesús, tratándolas no con pedantería teológica, sino con emocionante y ejemplar realismo cotidiano. Los versos exhalan un aroma de naturalidad y de ingenua frescura. Lope regresa a su infancia, se vuelve niño para sentir el goce y la alegría de éste ante un Nacimiento. Consciente del espíritu infantil que impregna su obra, dedica estas "niñeces" a su hijito Carlos. Pero también se siente padre al contemplar al Niño Jesús, y le dirige palabras del más tierno afecto al mismo tiempo que a María, su madre.

Los pastores cantan villancicos al recién nacido. El poeta los orea con el perfume de su Naturaleza, y sus elementos participan en

${ }^{15}$ Las citas pertenecen, respectivamente, a los sonetos $4,22,38,43,72$ y 85 . 
el coro de alabanza ${ }^{16}$. Entre ellos, el aire y el viento se introducen en la canción - iy con cuánta belleza son utilizados por el genio lírico de Lope!- (pp. 1228, 1274$)$ :

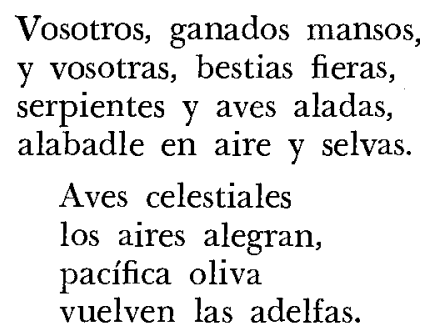

Pero también el aire enfría, en su desnudez, al Niño que llora y ríe como niño humano y que, siendo Dios, ha dado libertad a los vientos que le hieren (pp. 1284, 1288, 1304):

En unas pajas humildes, siendo sol, se encoge al hielo;

a la noche deja libre y da licencia a los vientos.

Niño amáis, Niño sentís,

Niño en humildes pañales, el hielo, el aire sufrís: ya hacéis niñerías tales, que lloráis, Niño, y reís.

El frío le encoge así, el aire, el hielo, aunque es Rey.

Por labios de Elifila, el poeta quiere dormir al Niño y suplica silencio a esos mismos vientos libres, en bellísima canción de cuna (p. 1295):

$$
\begin{aligned}
& \text { Palmas de Belén, } \\
& \text { que mueven airados } \\
& \text { los furiosos vientos } \\
& \text { que suenan tanto, } \\
& \text { no le hagáis ruido, } \\
& \text { corred más paso, } \\
& \text { que se duerme mi Niño, } \\
& \text { tened los ramos. }
\end{aligned}
$$

En el romance de la Virgen, ésta convoca a ángeles, astros y vientos para que oigan la buena nueva: ella es "madre de Amor hermoso" y su fruto redimirá a los hombres (p. 1233):

Oídme, cielos divinos.

Ángeles, estadme atentos.

${ }^{16}$ Idéntica función se advierte en el romance "Al nacimiento de Cristo", p. 111 . 
Detente, sol, a escucharme

de tu carrera en el medio.

Tú, velocísima luna,

pára tu cuerpo ligero.

Atiende, mar. Tierra, escucha.

Calle el aire y oiga el fuego...

Elisio celebra también a San José, aunque sabe que intentar alabarle dignamente es como tratar de "cifrar el mar y encarcelar el viento" (p. 1258).

El viento cruza aún por otros versos de la novela, como los que recita la Sibila a propósito de la torre de Babel, símbolo de cuantos se oponen a Dios (p. 1299):

Mayor torre levanta por el viento, y más oscura confusión espera quien sólo opone a Dios su pensamiento.

El aire participa en el drama de la Pasión de Cristo, como es evidente en dos romances: "A la oración del huerto" y "Al entierro de Cristo". Leamos algunos versos de este último (p. 124):

Cielo y tierra previnieron

el triste entierro, enlutando

la tierra, los edificios,

y el cielo, los aires claros.

Todas las hachas del cielo

iban delante alumbrando...

El Isidro (1599) es un relato poético que narra la vida del patrón de Madrid. Estilísticamente, marca en la lírica de Lope la transición del influjo popular del Romancero a las tendencias cultas. Abundan las notas realistas llenas de naturalidad, pero también es visible cierta hinchazón. En conjunto, es un poema encantador, sobre todo cuando percibimos las resonancias del Romancero. Lope entremezcló deliciosamente lo simple y sencillo con lo fantástico: escenas rústicas y agrestes con visiones de ángeles ${ }^{17}$ que labran campos y dialogan con Isidro. Un ángel define el Espíritu como viento de Amor: "El Espíritu se llama / viento que en amor inflama, / gracia, consuelo perfeto..." (p. 393). Cuando el ángel regresa al cielo, un vuelo de palomas se levanta en el aire (p. 399). El viento aparece también como fondo de la procesión que lleva en andas a la Virgen de Atocha, después de casarse don Lope con Clara y don Diego con doña Lucía, y de hacerse cristianos Otomán y Zara (p. 454). El aire

${ }^{17}$ Estas visiones nos han sugerido el subtítulo que encabeza esta sección dedicada a la presencia del viento en poemas en que trasciende una significación religiosa. 
está presente cuando Isidro muere y Dios manda unos ángeles que lleven su alma al cielo (p. 462):

Que si es del rey el privado

de todos siempre estimado,

él de Dios, ángeles, cielo, sol, luna, estrellas y suelo, agua, fuego y aire honrado.

También San Hermenegildo es animado por los ángeles en tanto que "por los aires siembran / maná de lirios azules / y cándidas azucenas" (Rimas divinas, p. 232). Parecida visión celeste se entrevé en el romance "A la dichosa muerte de Sor Inés del Espíritu Santo", donde el poeta pide a los espíritus celestiales que siembren de azucenas blancas los jardines eternos, "hasta el campo de la luna / las tres regiones del viento" (p. 233).

Para exaltar el misterio de la Comunión, Lope execra el alimento y la bebida que los hombres reciben de la tierra: "Porque el mundo miserable / les da por sustento polvo, / y para bebida aire" (Romancero espiritual, p. 126).

En las Rimas sacras hay otra alusión al sacramento eucarístico, en la evocación del milagro del maná israelita (Rima 53):

“¿Qué es esto?” - dijo, viendo cómo llueve

sobre las alas del templado viento

débil manjar envuelto en aura leve.

Aire y viento, en suma, dan londo, presiden o participan elementalmente en las efusiones religiosas de Lope de Vega. Un verso aislado, por último, relaciona bellamente al viento con el misterio de la Pasión de Cristo (Jerusalén, p. 697): “¿No ves que es vara / la Cruz, que el agua enfrena, el viento pasa?’"

\section{EL VIENTO DE LA MUERTE}

El viento de la muerte se desliza algunas veces por los poemas de Lope. Su imagen se muestra en la égloga dedicada a la muerte de fray Hortensio Félix Paravicino. Después de orear rústicamente la fuente y el huerto, cierra la égloga fúnebre aludiendo a la frágil condición humana: "viendo que es humo, viento y polvo cuanto / del fin que nos acerca nos divierte” (p. 254). En La hermosura de Angélica y en la Jerusalén conquistada, la muerte se hace patente en una atmósfera de violencia, creada por la guerra. Hiperbólicamente, el aire recoge las almas envueltas en sangre (p. $5^{21}$ ), y en cierto pasaje, una cabeza cortada sigue hablando en el viento... (p. 6o8).

Pero es en los Soliloquios de un alma a Dios -auténtico mea culpa febril, confesión sincerísima y desnuda- donde Lope ve a la 
muerte como un viento definitivo que ha de aventar su humano polvo último (p. 1026):

Queredme, pues tanto os quiero.

No aguardéis a que mañana me vuelva ceniza vana que lleve el viento ligero.

\section{ConcLusión}

Infinitas citas podríamos aducir aquí ${ }^{18}$ como nuevos ejemplos metafóricos del viento lopesco, o reiteraciones de los ya dados. El poeta, incansablemente, queriendo destacar -e hiperbolizar- la prisa de hombres, animales y naves, los compara siempre con el viento velocísimo ("corren a furia lo que el viento pudo", Jerusalén, p. 699). El viento es un símil comparativo predilecto de Lope: hombre dinámico por naturaleza, arrastrado siempre por la prisa en todo lo que hacía, se inclinaba a identificarse con el viento, fuerza con la que se igualaba en pasión y velocidad de sentimiento, en insaciable e incontenible ansia de vivir intensamente.

Lope matiza el viento con epítetos caracterizadores de índole variada al pintar paisajes o al elaborar imágenes. Esos epítetos registran los aspectos de la cambiante esencia del aire y del viento, radicalmente mudables, que obligan al poeta a preguntarse si existen reyes que puedan ponerles leyes (Jerusalén, p. 696). Así los céfiros son "suaves" (p. 248), el aire es "leve" (p. 618), el viento es "vagoroso" (p. 639), "vago" (p. 537), "vano" (p. 482), "sosegado" (p. 598), "mudo" (p. 696) o "contrario" (p. 877).

Este estudio temático del viento no ha intentado ser exhaustivo, pero sí lo bastante amplio para que resulte revelador. Las diversas categorías que hemos establecido nos muestran cómo toda una serie de valores metafóricos tiñen su imagen abundantemente, en barroca plenitud. Como siempre que se trata de Lope, los matices más artificiales - artificiosidad cultista, gongorina- quedan supeditados, humillados casi, a esa fuerza que salva su poesía de cuanto pueda tener de aluvión y de facilidad. Humanidad que, naturalmente, arrastra también significaciones de hondo pensamiento y dolorido sentir. El viento humano puede ascender -0 descender - hasta las profundidades filosófico-morales de un espíritu no exento de tales preocupaciones en medio de su intenso vivir.

Estos vientos de Lope son claros. Pocas veces - quizá nunca- se disfrazan en un metaforismo oscuro, sibilino. Pero sí los sentimos encrespados, en muchas ocasiones, de humanidad sencilla, de simple

${ }^{18}$ De sus piezas teatrales, sobre todo, pues sólo ocasionalmente hemos recordado algunas de ellas. 
cotidianidad. Claros, sí, pero no siempre tranquilos, según el rumbo de su vida. Suaves, violentos, dolorosos también.

Curiosamente, sin embargo, al pasar por la extensa obra lírica de Lope, al penetrarla en toda su extensión, la imagen metafórica del aire y del viento nos hace recordar, por una parte, al jónico Anaxímenes, y por otra a Heráclito. Expliquémonos. El primero consideraba el aire como la sustancia o sustrato universal del cosmos, porque era capaz de soportar la Tierra y los planetas: el aire tenía para él atributos de infinitud. Era el ápeiron, el infinito o ilimitado. (En un sentido, tal parece ser uno de los valores del aire y del viento lopescos). Heráclito, el descubridor del cambio continuo y universal de todo lo creado, eligió como símbolo el fuego (ique el viento atiza y aviva!), elemento original, porque el fuego es la más móvil y rápida de todas las sustancias. Sólo el cambio es real, decía el filósofo; todo está continuamente pasando, cambianḋo. El mundo es, así, eterno fuego, movimiento que consume, y sólo el orden de la sucesión de las cosas en el tiempo - la "razón", el "destino" del mundo- permanece siempre el mismo. El mundo es fuego porque es un suceder incesante.

Algo de estos filósofos presocráticos es visible en la concepción del mundo que se transparenta en Lope de Vega, por debajo de las ideas religiosas de su época, y como a despecho de sí mismo. De Anaxímenes, porque - tras examinar el uso temático del vientodescubrimos que el aire rodea, circula por todo el cosmos, que corre por bocas y narices, como signo de vida: su plasticidad es ilimitada. El aire, el viento, significa vidA en el cosmos poético de Lope. Además, decía Anaxímenes: "Como nuestra alma es aire, nos mantiene unidos, así el hálito y el aire abarcan el Todo cósmico"19. El mundo es aire: todo suceder es movimiento del aire; toda cualidad es aparente, y producto del estado de agregación del aire. El aire es lo infinito. Pero el aire de Lope arde casi siempre, aun cuando sea principio del mundo, aun cuando sea causa primera de las cosas. Y arde porque en él alienta el fuego heracliteano. El poeta encarna en este fuego, si no el principio, si el sentimiento, la realidad total del amor. Aparentemente es inestable, cambiante, transitorio; en el fondo, es un principio: es constante en su pasar, en su combustión, en su devenir.

Este examen del viento lopesco nos lleva a concluir que, en él, transitoriedad y permanencia le constituyen. La poesía, aquí, subordina a la filosofía, pero no la excluye: la absorbe, por decirlo así, y, energéticamente, viven, conviven inseparables. El viento poético

19 Nuestras citas proceden del volumen colectivo Los grandes pensadores: Antigüedad, Edad Media, Renacimiento, Revista de Occidente, Madrid, 1936, p. 33 . 
no es sólo viento de vida, sino también viento del pensar y del ser. Unificado en sus dos valores simbólicos, fluye sin descanso como el río del devenir heracliteano, cambiante, vivo: circula por todo el orbe -dentro y fuera del hombre- como el aire sin fronteras de Anaxímenes.

Según Aristóteles, el aire es la única sustancia que cambia por sí misma, incesantemente. Así es Lope de Vega, hombre-aire, hombre-viento, mudable por esencia y, en su mutabilidad, constante. El viento que entrevemos en sus poemas es logos, espíritu y razón, además de pasión vital y devenir, en proceso infinito de evolución: eterna y constante movilidad.

Estilísticamente, el viento lopesco es acaso la imagen temática que mejor representa a su creador, mudable como él, pero constante en su mudanza. Principio que informa sus cosmos poético, unido al fuego amoroso, no materia ígnea, sino fuerza que se enciende y apaga en sí misma, según una orden eterna y racional emanada del logos.

Pongamos punto final a este estudio temático-estilístico del viento lopesco devolviéndolo a su paz y silencio, con un verso del poeta que supo captarlo y expresarlo poética y filosóficamente (Jerusalén, p. 701).

y vueltos a sus cárceles los vientos.

Que duerman allí hasta que otro grande y excepcional poeta acierte a despertarlos y a libertarlos.

Indiana University.

Concha Zardoya 